\author{
Peter Schlögelhofer • Marcus Garzón \\ Claudia Kerzendorfer • Viktoria Nizhynska \\ Andreas Bachmair
}

\title{
Expression of the ubiquitin variant ubR48 decreases proteolytic activity in Arabidopsis and induces cell death
}

Received: 23 February 2005 / Accepted: 27 June 2005/Published online: 1 October 2005

(C) Springer-Verlag 2005

\begin{abstract}
The ubiquitin-proteasome pathway is the major route for protein degradation in eukaryotes. We show here that this pathway can be inhibited in Arabidopsis thaliana by expression of a ubiquitin variant that contains Arg instead of Lys at position 48 (ubR48). A major consequence of ubR48 expression is the induction of cell death. Cell death induction coincides with the appearance of reactive oxygen intermediates, but is independent of salicylic acid. We found changes in expression of some defense-related genes, but these changes are apparently insufficient to cause alterations in the response to a bacterial pathogen. Expression of ubR48 from an inducible gene allowed investigation of kinetic parameters of cell death induction. In the absence of additional stress factors, slow death processes dominate if the transgene is induced in seedlings older than 2 weeks. The inducible gene also allowed isolation of suppressor mutants. Expression of ubR48 may cause changes similar to inhibition of the proteasome, which also induces various forms of cell death. Thus, ubR48 is a tool to manipulate protein turnover and to probe cell death programs in plants.
\end{abstract}

P. Schlögelhofer · C. Kerzendorfer · V. Nizhynska

A. Bachmair

Institute of Botany, University of Vienna,

Rennweg 14, 1030 Vienna, Austria

M. Garzón · A. Bachmair ( $)$

Department of Plant Developmental Biology,

Max Planck Institute for Plant Breeding Research,

Carl-von-Linné-Weg 10, 50829 Cologne, Germany

E-mail: bachmair@mpiz-koeln.mpg.de

Tel.: + 49-221-5062265

Fax: + 49-221-5062207

Present address: P. Schlögelhofer · C. Kerzendorfer Department of Chromosome Biology, Vienna Biocenter 2, University of Vienna, Dr. Bohr-Gasse 1, 1030 Vienna, Austria

Present address: V. Nizhynska

Center for Brain Research, Medical University of Vienna, Spitalgasse 4, 1090 Vienna, Austria
Keywords Cell death $\cdot$ Pathogen response $\cdot$ Proteolysis inhibition $\cdot$ Reactive oxygen intermediates $\cdot$ Salicylic acid Senescence $\cdot$ Ubiquitin-proteasome pathway

Abbreviations CaMV: Cauliflower mosaic virus - Dex: Dexamethasone - DHFR: Dihydrofolate reductase · GUS: $\beta$-glucuronidase from $E$. coli $\cdot$ HR: Hypersensitive response $\cdot$ Me-JA: Jasmonic acid-methyl ester .

MTX: Methotrexate - NBT: Nitroblue tetrazolium · PCD: Programmed cell death - ROI: Reactive oxygen intermediate $\cdot$ SA: Salicylic acid

\section{Introduction}

Programmed cell death (PCD) is an integral part of plant development, and can be a response to biotic or abiotic stress (Gray 2004). There are both fast forms of plant PCD, as exemplified by the hypersensitive response to pathogens, and slower, probably graded forms as found during senescence. It is unclear at present to which extent these different forms of plant PCD share components or mechanisms. Whereas mechanistic insights into PCD in animals is comparatively advanced, a molecular understanding of cell death in plants is just emerging. There are no candidate genes in plants with clear orthology relationship to animal cell death components (Aravind et al. 2001).

There is, however, limited similarity between animal and plant cell death at the phenomenological level. For instance, caspase inhibitors can prevent certain forms of plant cell death (for review, see van der Hoorn and Jones 2004). Recent investigations also suggest that mitochondria play an equally important role in plant cell death as in animals (Christensen et al. 2002; Curtis and Wolpert 2002; Matsumura et al. 2003), and expression of certain components from animal cell death pathways can have surprisingly specific effects when expressed in plant cells (Lacomme and Santa Cruz 1999; KawaiYamada et al. 2001; Baek et al. 2004). Similar to animal 
pathogens, plant pathogens may express factors that antagonize PCD. The finding that individual representatives of this diverse group of proteins do not block all forms of plant PCD indicates that, as in animals, several pathways exist to induce and/or execute PCD in plants (Jamir et al. 2004).

We have discovered previously that inhibition of the ubiquitin-proteasome pathway of protein turnover induces cell death in plants (Bachmair et al. 1990). Modification of proteins by covalent addition of the small protein modifier ubiquitin is essential for many processes in plants (for recent reviews, see Bachmair et al. 2001; Hare et al. 2003; Moon et al. 2004; Schwechheimer and Schwager 2004; Smalle and Vierstra 2004). In the ubiquitylation process, ubiquitin's carboxyl terminus is linked via a thioester bond to the active site Cys residue of ubiquitin-activating enzyme E1. From there, the activated ubiquityl residue is transferred to a ubiquitinconjugating enzyme, E2. Transfer to substrates, to form an isopeptide bond with the $\epsilon$-amino group of an internal Lys residue, is catalyzed by one of many ubiquitin protein ligases, E3s, which provide substrate specificity (Pickart 2001). Substrates which are modified by addition of multiple ubiquityl residues, linked sequentially onto each other via Lys at position 48, are targeted for destruction by the proteasome (Lam et al. 2002).

When expressed in plant cells, ubiquitin in which Lys 48 is replaced by Arg (called ubR48 in the following) is conjugated to proteins (Ling et al. 2000). Because ubiquitin chains formed by linkage via Lys 48 can no longer be formed on ubR48, the variant inhibits ubiquitin-dependent proteolysis. In contrast, other ubiquitylation processes (e.g., monoubiquitylation events, which form approximately half of all cellular ubiquitin conjugates, or alternative ubiquitin-ubiquitin linkages, such as those via Lys 63, the second-most abundant ubiquitin chain in yeast cells; Peng et al. 2003) are not affected when tested in vitro. However, this selectivity has not yet been proven for in vivo expression of ubR 48 .

In tobacco, expression of ubR48 leads to developmental abnormalities, induction of defense genes and cell death (Bachmair et al. 1990; Becker et al. 1993; Conrath et al. 1998). A probably similar effect can be achieved by inhibition of the proteasome (Kim et al. 2003). A connection between ubiquitylation and plant cell death is also supported by analysis of the rice gene spotted leaf 11 (spl11), which encodes a U-box ubiquitin ligase. A lossof-function mutation in spll1 results in spontaneous cell death in the form of small lesions (Zeng et al. 2004). Senescence, a slow form of PCD, also uses the ubiquitin proteasome system for regulation and/or execution, as evidenced by mutants in senescence with defects in ubiquitylation (Woo et al. 2001; Yoshida et al. 2002).

Several connections between PCD in animals and the ubiquitin-proteasome pathway are known in molecular detail (for reviews, see Yang and $\mathrm{Yu}$ 2003; Vaux and Silke 2005). In particular, many inhibitors of apoptosis proteins (IAPs) have ubiquitin ligase activity and target pro-apoptotic proteins for degradation (MacFarlane et al. 2002; Bartke et al. 2004). IAP activity apparently regulates initiation of apoptosis. During the execution phase of apoptosis, the ubiquitin-proteasome pathway is shut down (Sun et al. 2004). Consistent with an antiapoptotic role for ubiquitylation, inhibition of the ubiquitin-proteasome pathway in human myeloma cells induces both the "internal" death pathway triggered by release of cytochrome $\mathrm{c}$ and other components from mitochondria, and "external" pathways normally mediated by death receptors (Kisselev and Goldberg 2001; Mitsiades et al. 2002). As mentioned above, orthologs to components that link ubiquitylation pathways to animal apoptosis are not readily identified in plants, and the existing data concerning pathway inhibition do not provide mechanistic details.

In order to learn more about the relationship between ubiquitin-proteasome dependent protein turnover and PCD in plants, we generated and characterized Arabidopsis plants expressing ubR48, an inhibitor of the ubiquitin-proteasome pathway. ubR48 expression leads to accumulation of a normally short-lived cyclin-GUS fusion protein, and to developmental defects most easily explained by localized and/or premature cell death. One goal of the current study was to delineate the extent of overlap between the PCD induced by ubR48 expression, and other, already better characterized forms of PCD. Cell death events observed after ubR48 expression are independent of the biotic stress mediator SA, as judged by the small influence of salicylate hydroxylase expression on the process. The difference between ubR48-induced PCD and defense response is also underscored by the finding that an SA-inducible marker gene (PR-1) as well as a JA-inducible marker gene (Thil.2) are not induced in transgenic ubR48 expressing Arabidopsis plants. Further insights were gained by studies with a dexamethasone-inducible construct, demonstrating that kinetics of seedling cell death by ubR48 expression in the absence of additional stress factors is considerably slower than the hypersensitive response to pathogens. Mutants that were obtained are more resistant to ubR48-induced PCD. One of these mutant lines is also more resistant to a proteasome inhibitor, MG 132.

\section{Materials and methods}

\section{Plants and microbes}

All plants used in this study were Arabidopsis thaliana ecotype Col-0. Plant line Cyc-Gus (cf. Donnelly et al. 1999) was a kind gift of J. Celenza, (Boston University, Boston, USA). The plant line expressing nahG (P. putida $n a h G$ gene encoding salicylate hydroxylase, Acc. Nr.: X83926) was obtained from Syngenta Biotechnology, Inc. (Research Triangle Park, USA). Plants were germinated on media containing MS salts and 1\% sucrose, and were usually transferred to soil after 3 weeks. Agrobacterium strain C58C1pCV2260 (grown with $50 \mu \mathrm{g} / \mathrm{ml} \mathrm{kanamycin} \mathrm{and} 100 \mu \mathrm{g} / \mathrm{ml}$ rifampicin for 
selection) was used for plant transformation. Pseudomonas syringae DC3000 grown in King's B medium supplemented with $100 \mu \mathrm{g} / \mathrm{ml}$ rifampicin and $30 \mu \mathrm{g} / \mathrm{ml}$ kanamycin was used for infection experiments on Arabidopsis Col-0 leaves. The latter bacteria contained either vector pVS61 alone, or with insertion of avirulence gene avrRPM1 (kind gift of J. Dangl and Miguel A. Torres, University of North Carolina).

\section{Plant treatments}

Arabidopsis was transformed by the root transformation method (Valvekens et al. 1988), with the exception that hygromycin was used instead of kanamycin for selection of transformation events. For treatment with SA and Me-JA, plants were germinated on plates without selection and grown for 2 weeks under long day conditions. Twenty-four hours prior to harvest, plants were either left without treatment, or $500 \mu \mathrm{l}$ of sterile $\mathrm{d}_{2} \mathrm{O}, 500 \mu \mathrm{l}$ of methyl jasmonate (Me-JA) solution (3-oxo(2 Z-pentenyl)-cyclopentane acetic acid methyl ester, Duchefa, Haarlem, The Netherlands) or $500 \mu \mathrm{l}$ salicylic acid (SA) solution (2-hydroxybenzoic acid, Sigma) were spread on the surface of the media plate. The final concentration of Me-JA and SA in the plates was $100 \mu \mathrm{M}$. The stock solutions were $100 \mathrm{mM}$ in $96 \%$ ethanol and diluted in $\mathrm{dH}_{2} \mathrm{O}$. Plant material was frozen in liquid nitrogen and stored for RNA isolation. Dexamethasone (Sigma) and MG132 (Biomol, Hamburg, Germany) were added to culture media from stock solutions prepared in dimethylsulfoxide (DMSO). Control cultures contained the same amount of DMSO, which never exceeded $2 \% \mathrm{v} / \mathrm{v}$. Dex addition after germination of seedlings on plates was carried out by pre-dilution of stock solution in $2 \mathrm{ml}$ of water followed by distribution on the surface of the petri dish. For RNA isolation from mutants, plants were grown on plates for 6 weeks. Thereafter, $1 \mathrm{ml}$ of $0.6 \mathrm{mM}$ Dex solution was distributed on each plate. Plants were harvested $8 \mathrm{~h}$ later.

For bacterial inoculation, Pseudomonas syringae DC3000 were grown overnight and diluted to an $\mathrm{OD}_{600}$ of 0.02 in $10 \mathrm{mM} \mathrm{MgCl}$. Plants were germinated on plates and grown on soil in a $14 \mathrm{~h}$ light $/ 10 \mathrm{~h}$ dark cycle for 3 to 4 weeks. Plants were infiltrated using a disposable plastic syringe. $0,1,2,3$ or 4 days after inoculation, 3 to 4 leaves were harvested into an Eppendorf tube. The fresh weight was determined and $1 \mathrm{ml}$ of bacterial extraction buffer (10 mM MgCl, $0.02 \%$ Silwet 77) was added. Tubes were agitated at $30^{\circ} \mathrm{C}$ for $1 \mathrm{~h}$. The extracted bacteria were plated as serial dilutions (1, 1:10, 1:100, 1:1000) onto King's B (Rif /Kan) plates. After 1 day, colonies were counted under a binocular microscope and values were normalized to leaf fresh weight.

\section{Vector construction}

Transgene vector $\mathrm{B} 4 \mathrm{M}$ was assembled in the following way: plasmid pRTRV4, a construct similar to pRTRV32
(Bachmair et al. 1990), but with tetra-ubiquitinR48 instead of 32 units, was combined with a BamHI $\mathrm{XbaI}$ fragment encoding murine DHFR as contained in vector pCHUM (Bachmair et al. 1993), but with an L22R amino acid change, to give pRTRV4MR. The HindIII insert fragment from pRTRV4MR was cloned into p35H (Schlögelhofer and Bachmair 2002) in an orientation to align the two $35 \mathrm{~S}$ enhancers, to give construct B4M.

Construct pTARV8 for Dex-inducible expression of ubR48 was obtained by modification of pRTRV8, a construct similar to pRTRV32 (Bachmair et al. 1990), but with 8 instead of 32 ubiquitin R48 units. After digestion with BamHI and partial digestion with SalI, the annealed oligonucleotides TCG ACC TTA CAT CTT GTC TTA AGA CTT AGA GGT GGT ATG G and GAT CCC ATA CCA CCT CTA AGT CTT AAG ACA AGA TGT AAG G were inserted. The inserted sequence links the eight ubiquitin R48 units to a carboxyl-terminal murine dihydrofolate reductase in one continuous reading frame. An XhoI HindIII fragment that contains this ORF and the CaMV 35S poly(A) addition site was excised and inserted into XhoI HindIIIdigested vector $\mathrm{pSK}+$. An XhoI SpeI fragment from the ensuing vector was cloned between the XhoI and SpeI sites of vector pTA7002 (Aoyama and Chua 1997) to give pTARV8.

\section{RNA analysis}

RNA was prepared using the Qiagen RNeasy Plant Mini Kit (Qiagen) according to the manufacturer's recommendations. Ten micrograms of total RNA was applied per lane in gel blot experiments. The RNA was sizeseparated on formaldehyde containing agarose gels with a MOPS containing running buffer, transferred to nylon membranes (Amersham Hybond N, Amersham Pharmacia), and hybridized with probes as described (Ausubel et al. 1987). To obtain hybridization probes, PR-1 cDNA in plasmid pBS (Uknes et al. 1992) was digested with EcoRI and $X h o$ I to obtain a 750-bp fragment. PR-2 cDNA in plasmid pBS (Uknes et al. 1992) was digested with EcoRI and $X h o I$ to obtain a 1,180-bp fragment. PR-5 cDNA in plasmid pBS (Uknes et al. 1992) was digested with KpnI and BamHI to obtain a 980-bp fragment. Pdf 1.2 plant defensin cDNA in vector pZL1 (Penninckx et al. 1996) was digested with SalI and NotI to obtain a 490-bp fragment. Thi 2.1 thionin cDNA in vector pBS (Epple et al. 1995) was digested with EcoRI to obtain a 700-bp fragment. Mouse DHFR cDNA in vector pRT103 (Bachmair et al. 1993) was digested with HindIII and BamHI to obtain a 680-bp fragment. A chlorata 42 genomic fragment in plasmid pBS (Ch42, X91411, Atch42 wt; Koncz et al. 1990) was digested with XhoI to obtain a 1750-bp fragment (loading control). A pSK vector containing ribosomal protein L4 (kind gift of Dr. Csaba Koncz, MPIZ) was digested with EcoRI and HindIII to obtain a 750-bp 
fragment (alternative loading control). For RNA size estimation, an RNA ladder (Gibco BRL) was run alongside the samples and visualized with ethidium bromide. For labeling of hybridization probes, the Random Prime DNA Labeling Kit (Roche) was used according to the manufacturer's instructions. Hybridized and washed filters were exposed to X-ray films (Kodak X-omat AR, Kodak), or analyzed by phosphorimager (cf. Fig. 11).

\section{DNA analysis}

Plant material from liquid culture was dried on filter paper and ground to a fine powder in liquid nitrogen. The powder was weighed and used for DNA preparation using a Qiagen DNeasy plant maxi kit (Qiagen) as recommended by the manufacturer. DNA was quantified spectrophotometrically and analyzed by agarose gel electrophoresis for size distribution.

\section{Histological staining}

Transgenic plants were grown in petri dishes and stained to reveal GUS activity as described (Schlögelhofer et al. 2002). To visualize ROIs, plants were grown on soil under long day conditions. Samples (siliques) were taken and vacuum infiltrated with buffer $\left(10 \mathrm{mM} \mathrm{NaN} \mathrm{N}_{3}\right.$, $10 \mathrm{mM}$ K-phosphate, $\mathrm{pH}$ 7.8). Thereafter, the samples were immersed in buffer containing $0.1 \%$ NBT for 15 to

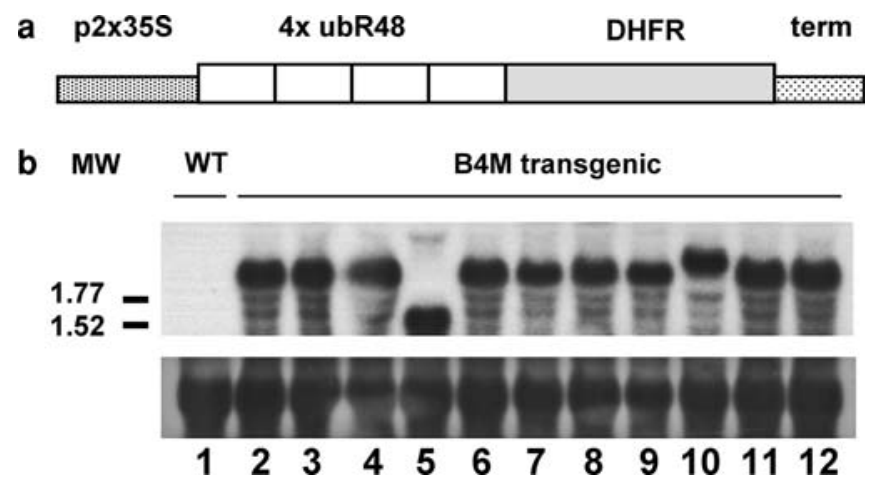

Fig. 1 a, b Schematic representation of transgene used to express ubiquitin variant (a) with Arg instead of Lys at position 48 in Arabidopsis plants. p2x35S, promoter of the $35 \mathrm{~S}$ transcript of CaMV with duplicated enhancer region; $4 \times$ ubR48, four in-frame head-to-tail repeats of the ubR48 sequence that are cleaved by ubiquitin-specific proteases into single ubR48 units; DHFR, sequence of mouse DHFR cDNA in the nontranslated $3^{\prime}$ trailer for mRNA detection without cross-hybridization to endogenous ubiquitin genes; term, poly A addition sequence of the CaMV 35S transcript. b RNA gel blot analysis of ubR48 expressing transgenic lines. Top, DHFR probe to detect transgene RNA; bottom, ribosomal protein probe as a loading control. $M W$ indicates position of RNA size standards of 1.77 and $1.52 \mathrm{~kb}$. Plants of lanes $3,8,9$ and 11 were used to obtain homozygous lines. All four homozygous lines showed phenotypic characteristics as described in the text
90 min. After rinsing the plants with water, they were de-stained in $70 \%$ ethanol (adapted from Overmyer et al. 2000).

\section{Results}

Expression of a ubiquitin variant in Arabidopsis induces cell death

Construct B4M (Fig. 1a) allows the expression of a modified tetra-ubiquitin in plants under control of the strong constitutive $2 \mathrm{xCaMV} 35 \mathrm{~S}$ promoter. All four ubiquitin units contain a Lys-to-Arg change in position 48. Upon in vivo translation, the polyprotein is cleaved by ubiquitin-specific proteases into four ubR48 units, which are apparently used like endogenous wild-type ubiquitin for conjugation to substrates, but cannot support formation of ubiquitin-ubiquitin linkages via Lys 48. In order to allow detection of transgene mRNA with a probe distinct from the potentially cross-reacting ubiquitin sequence, we included a mouse DHFR cDNA sequence in the mRNA $3^{\prime}$ region as an untranslated extension. After transformation of Arabidopsis Col-0 plants with this construct, we noticed that some of the transgenic plants showed extensive areas of cell death on leaves and ultimately died (Fig. 2c, d vs. a). Other lines, however, had a milder phenotype and survived till seed set. Homozygous plants of four lines with intermediate to high expression level of the transgene (lanes 3,8,9 and 11 of Fig. 1b) were generated. All of these showed cell death symptoms as described below. The severity of phenotype apparently correlated with the expression level of the transgene.

Among the homozygous lines, line B4M16, one of the lines with high expression level (lane 11 of Fig. 1b), was chosen for detailed investigations. This line contains a single locus insert and has no apparent developmental defect in the hemizygous state, but distinct abnormalities when the transgene is in the homozygous state, which we ascribe to the increased expression level of two copies of the transgene locus. In homozygous form, about one-third of the seedlings of line B4M16 die on agar plates with concomitant necrosis of leaves and cotyledons (Fig. 2b). After transfer to soil, a similar fraction of plants shows leaf cell death and dies, whereas the rest of the plants are able to form shoots and set seed.

The most distinct deviation of B4M plants from wild type is the presence of bent siliques (Fig. 3a). We reasoned that the cause of this phenotype might be localized cell death at the base of the silique. In particular, preferential death of cells on the adaxial side, combined with continued growth of abaxial cells, might be the reason for silique bending. In order to support this hypothesis, we stained the abnormal structures with NBT, a colorless compound that turns blue upon reaction with oxidants such as superoxide. The reaction is routinely used to detect the reactive oxygen intermediate (ROI), 
Fig. 2 a-d Expression of ubiquitin variant ubR48 in Arabidopsis leads to cell death in leaves and other tissues. a Cauline leaf of healthy control plant. b Seedlings from homozygous transgenic line B4M16 die stochastically at early stages. c, $\mathbf{d}$ Cauline leaves from ubR48-expressing plants showing cell death symptoms
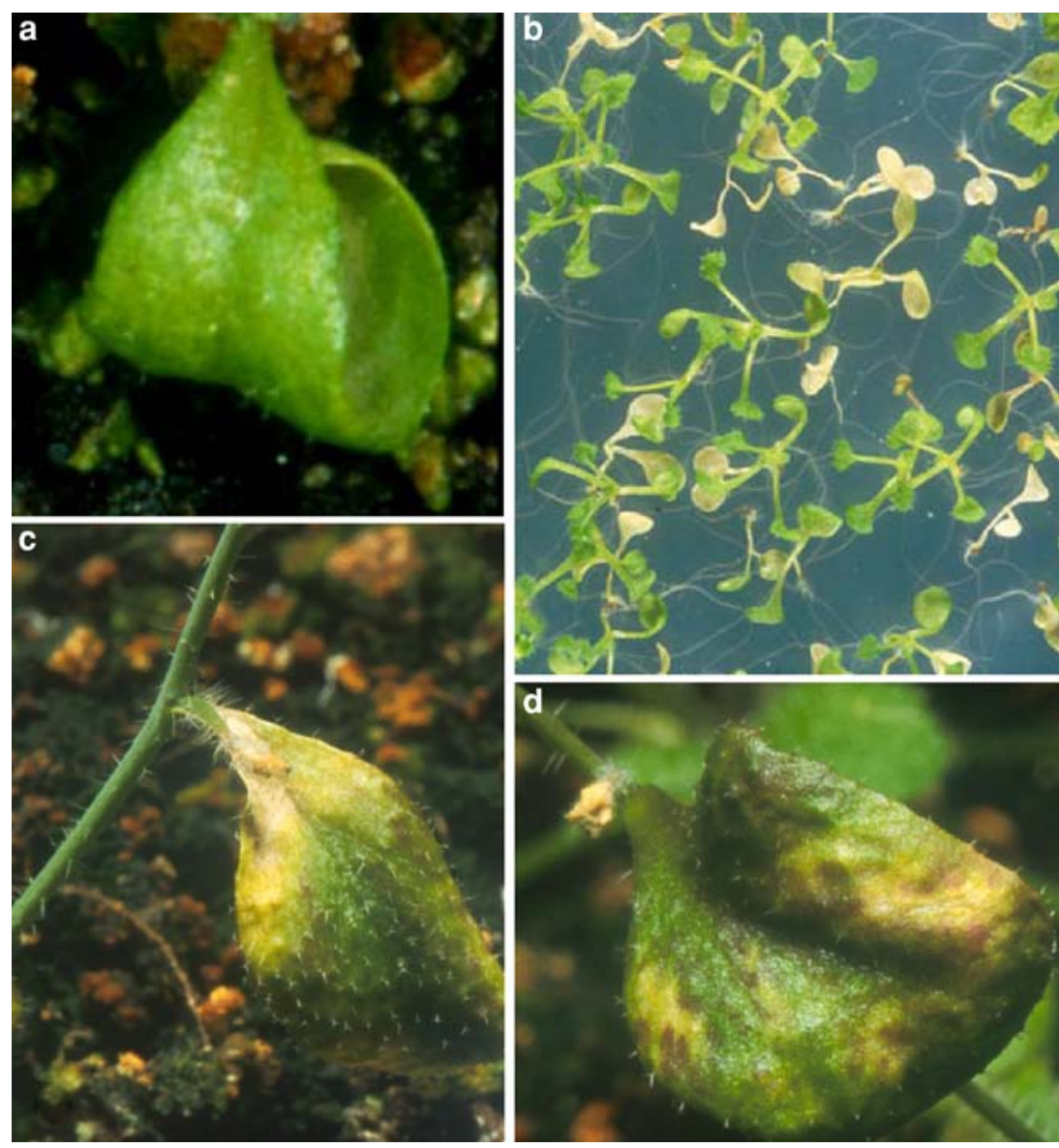

superoxide, in plant material (Wohlgemuth et al. 2002). We find that ROIs are indeed present on the adaxial side, at the base of bent siliques (Fig. 3b, c). Because we observed bent siliques in all four lines that were bred to homozygosity for the B4M transgene (see Fig. 1b, lanes $3,8,9$ and 11 ), we can rule out that this phenotype is due to disruption of gene function by T-DNA insertion in line B4M16.
Expression of ubiquitin variant ubR48 increases the half-life of a short-lived protein

We wanted to find out whether ubR48 increases the halflife of proteolytic substrates. A fusion between a B-type cyclin (CycB1;1; At4g37490), and GUS, under control of the cyclin promoter, normally stains dividing cells of the meristem (Donnelly et al. 1999). When present in the
Fig. 3 a-c Bent silique phenotype. a Plants expressing ubR48 frequently showed bending of siliques. b, c Staining of tissue samples with NBT to reveal ROIs indicates that both zones of developmentally programmed cell death (arrowheads) and zones of pathological cell death (arrow) accumulate ROIs
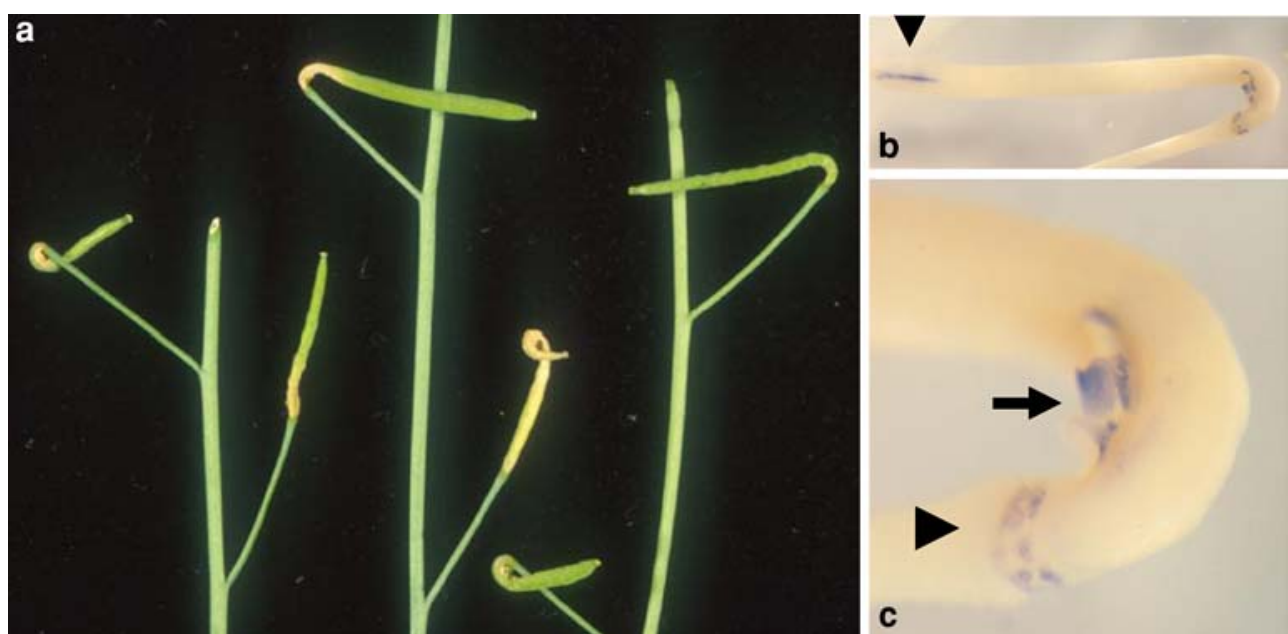
homozygous B4M background, we see a large increase in the number of cells actively stained by GUS substrate, indicative of a substantial increase in the amount of fusion protein present (Fig. 4a, b vs. c). This increase is not paralleled by an increase in transcription rate, which remains essentially identical to transcription in the wildtype background (Fig. 4d). We therefore conclude that in B4M16 plants, a protein known as a substrate of the ubiquitin-dependent degradation pathway (Glotzer et al. 1991; Zachariae and Nasmyth 1999) has an increased half-life.

Cell death caused by ubR48 expression is independent of salicylic acid and induces a subset of pathogenesisrelated genes

In earlier experiments, which used tobacco plants for analysis of ubR48 effects, an increase in the level of salicylic acid (SA) was detected (Conrath et al. 1998). We introduced the bacterial $n a h G$ gene, coding for the SA-degrading enzyme salicylate hydroxylase, to investigate the influence of SA on the phenotypes. A transgenic line carrying a $n a h G$ transgene was crossed to line B4M16, and phenotypes were observed in homozygous progeny plants. Interestingly, the double transgenic line had the same apparent number of dying progeny as line B4M16. Figure 5 shows death at the rosette stage of growth. One characteristic difference of B4M16 versus B4M16 $n a h G$ plants was that dying plants of the latter genotype seemed to accumulate anthocyanin to a greater extent than B4M16 plants without nahG transgene (Figs. 2, 5). We conclude that SA is not an intermediate in cell death induction via inhibition of the ubiquitinproteasome pathway.
Expression of ubR48 leads to changes in gene expression. We monitored a number of genes involved in plant defense (Fig. 6). In tobacco, the SA-inducible gene PR-1 is induced by ubR48 expression, consistent with the presence of SA in these plants. Arabidopsis plants containing the ubR48 transgene, however, do not express PR-1. The absence of PR-1 mRNA is not due to inability to induce this defense-related gene, as the exogenous application of SA (Fig. 6, probe PR-1, lanes 3 and 11) induces PR-1 mRNA, even to a higher extent than in wild-type plants. The presence of a $n a h G$ gene efficiently suppresses this induction (Fig. 6, probe PR-1, lanes 7 and 15). The expression pattern of PR-1 is consistent with low levels of SA in plant line B4M16.

Another defense-related gene, PR-2, is constitutively induced in plant line B4M16 and, to a lesser extent, in line B4M nahG (Fig. 6, probe PR-2). PR-2 mRNA levels can be decreased by exogenous Me-JA (Fig. 6, probe PR-2, lane 12), and in several experiments we saw an increase after application of SA (data not shown). An antagonistic action of SA and JA on the expression of certain defense-related genes has been reported before (Schenk et al. 2000; Spoel et al. 2003). Expression of Thi 2.1, a thionin gene of Arabidopsis (Bohlmann et al. 1998), depends strictly on the exogenous addition of Me-JA under our experimental conditions (Fig. 6, probe Thi). The expression pattern thus indicates that B4M transgenic plants do not contain elevated levels of Me-JA. In contrast, the defensin gene Pdf 1.2, which was also found to be inducible by JA (Penninckx et al. 1996; Manners et al. 1998), is induced in absence of exogenously added Me-JA in B4M transgenic plants (Fig. 6, probe Pdf). Exogenous application of SA to B4M plants does not appreciably decrease the expression level of Pdf 1.2. However, a complete elimination of
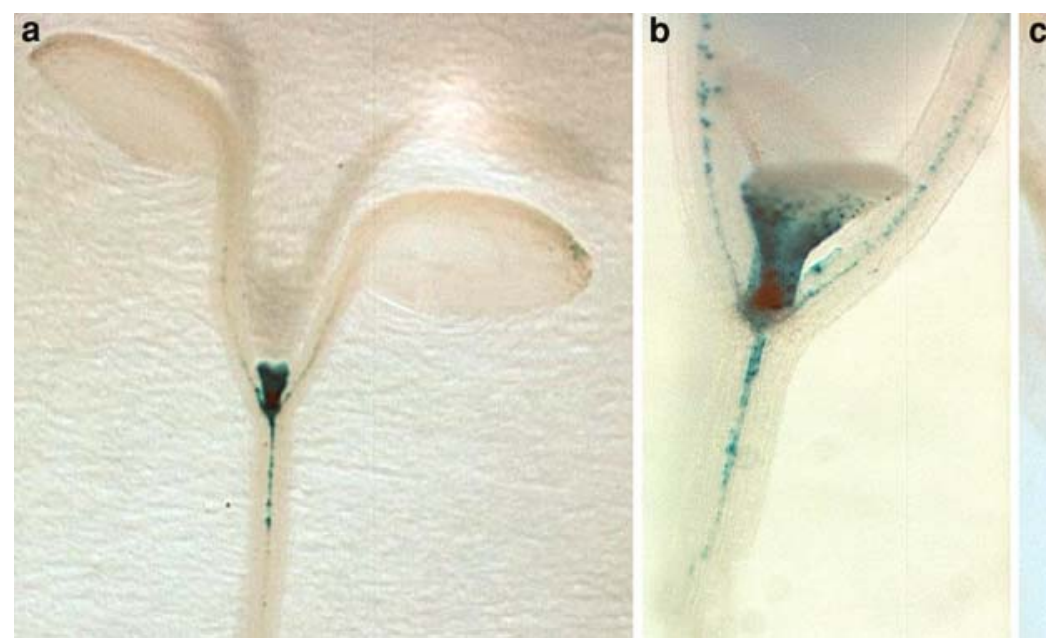

c

Fig. 4 a-e Extension of the half-life of a cyclin-GUS fusion protein in ubR48-expressing plants. Plants expressing both the B4M transgene and a cyclin-GUS fusion under control of the cyclin promoter accumulate more GUS enzyme $(\mathbf{a}, \mathbf{b})$ than plants without B4M transgene (c). This increase in enzyme activity is not paralleled by an increase in the transcription rate (d, GUS probe; e, Chlorata 42 cDNA probe as a loading control), indicating that the normally short-lived fusion protein is stabilized in plants expressing ubiquitin variant ubR48 
Fig. 5 Suppression of SA accumulation does not interfere with cell death induction by ubR48. Plants expressing both the B4M gene and the SAmetabolizing $n a h G$ gene show death symptoms comparable to those of plants containing only the B4M transgene. The figure shows two dying B4M nahG plants at the rosette stage
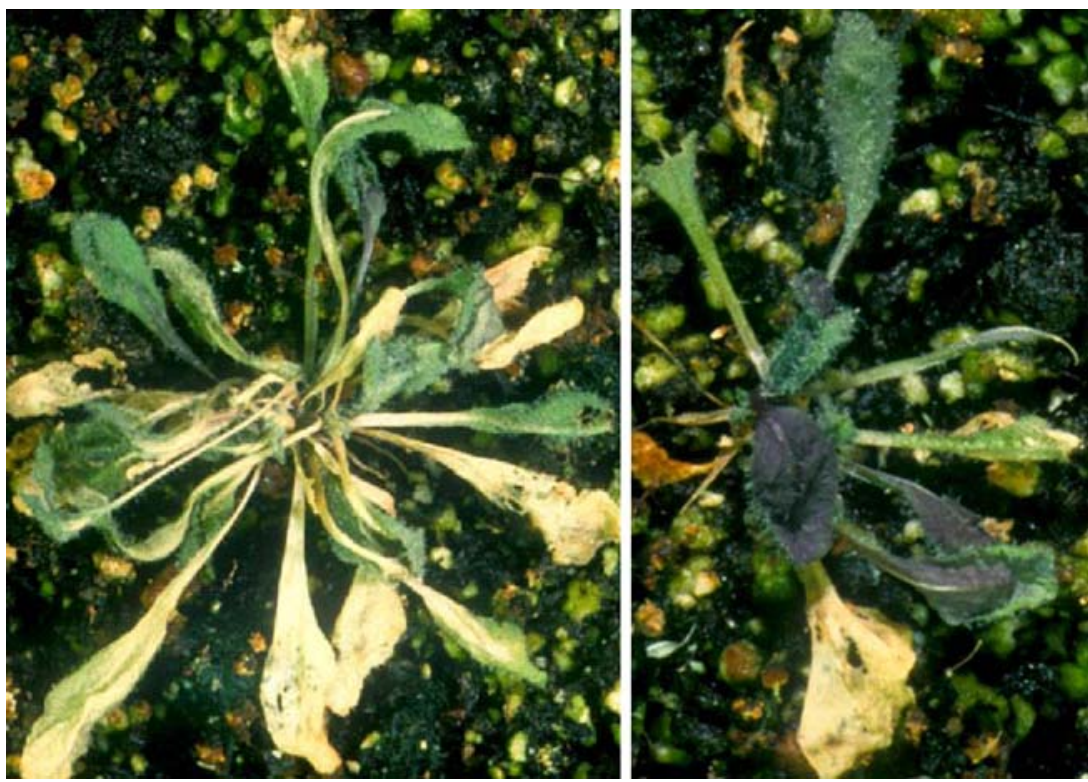

SA response by inclusion of a $n a h G$ transgene decreases its expression (Fig. 6, probe Pdf, lanes 9-12 vs. 13-16). Generally, it appears that induction of defense-related genes in B4M test plants occurs mainly via a "nonhormonal" route and therefore does not affect genes which strictly depend on either SA, or JA.
Bacterial infection of ubR48 expressing plants

Changes in defense-related gene expression, as observed in the B4M plant line, may have consequences for the course of infection by pathogens. For this reason, we infected line B4M with bacteria, Pseudomonas syringae
Fig. 6 RNA gel blot experiments demonstrate differences in the expression of defense-related genes. Plant lines wild-type Col-0 (WT), Col-0 expressing a $n a h G$ gene (nahG), Col-0 expressing a B4M transgene (B4M), and the double transgenic line (B4M nahG) were subjected to a number of treatments (lanes 1 , 5, 9 and 13, no treatment (no tr.); lanes 2, 6, 10 and 14, leaves were treated with water $24 \mathrm{~h}$ prior to harvest $\left(\mathrm{H}_{2} \mathrm{O}\right)$; lanes 3 , 7,11 and 15 , leaves were treated with SA $24 \mathrm{~h}$ prior to harvest (SA); lanes 4, 8, 12 and 16 , leaves were treated with Me-JA $24 \mathrm{~h}$ prior to harvest (JA)). RNA from leaves was taken for a gel blot experiment. The probes used were: DHFR, mouse dihydrofolate reductase to monitor B4M transgene expression (see Fig. 1); ch42, Chlorata 42 loading control; PR-1, PR-1 cDNA; PR-2, PR-2 cDNA; Thi, Thi2.1 cDNA; Pdf, Pdf1.2 cDNA

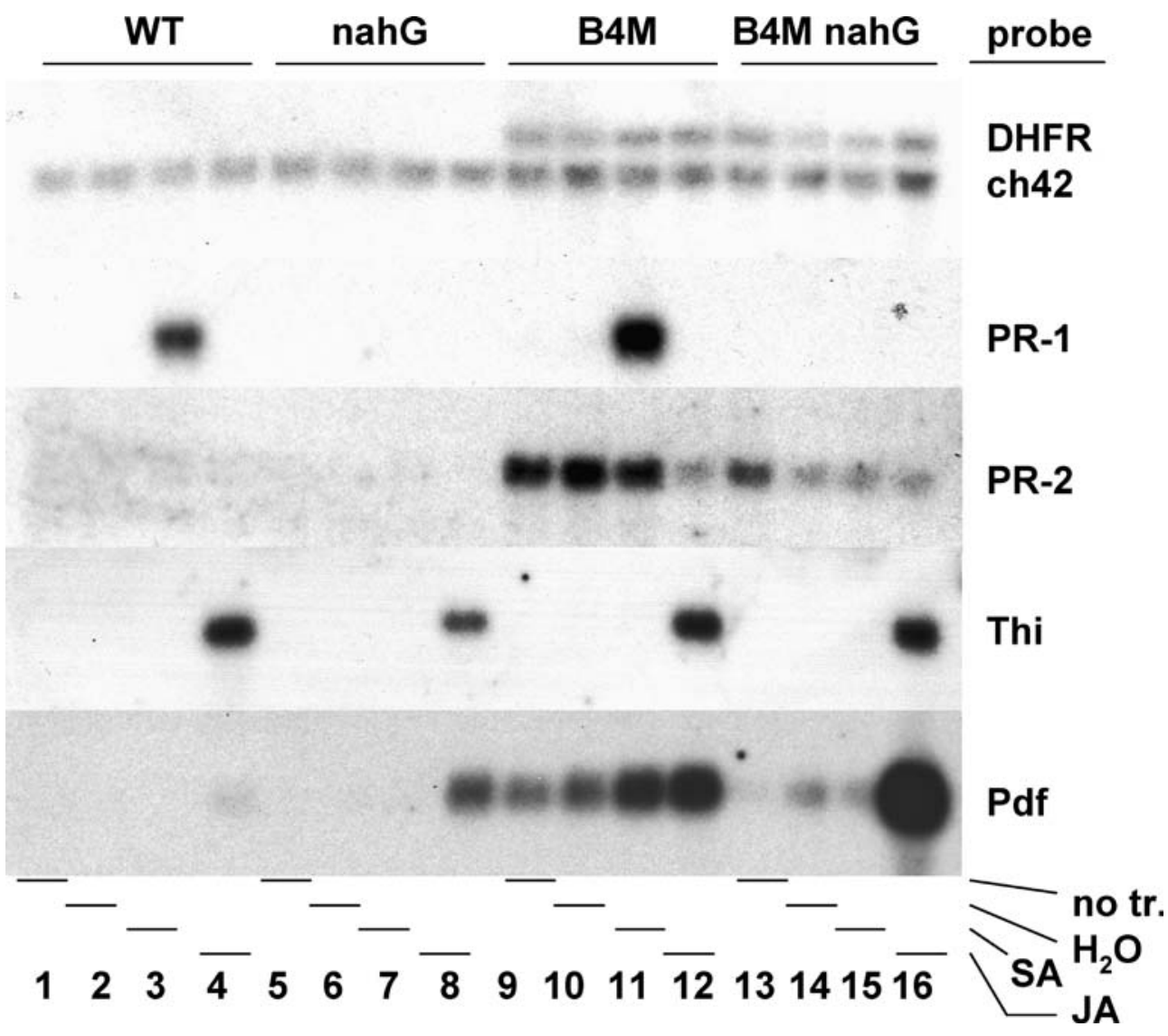


DC3000, a virulent pathogen on Arabidopsis thaliana ecotype Col-0. Figure 7a shows, however, that the B4M transgene does not change the growth pattern of the bacteria. In another series of experiments, the bacteria contained a plasmid carrying avirulence gene avrRPMI from Pseudomonas syringae pv. maculicola (Ritter and Dangl 1995), which interacts with resistance gene RPMI of Col-0 (Grant et al. 1995) to initiate a hypersensitive response (HR). We found that presence of the B4M16 transgene does not compromise the HR (Fig. 7b). Three days after inoculation, viability of bacteria in leaf material is low and does not differ significantly between Col-0 and line B4M16.

\section{Inducible expression of ubiquitin variant ubR48}

The experiments with the $\mathrm{B} 4 \mathrm{M}$ transgene indicated that cell death triggered by inhibition of the ubiquitin-
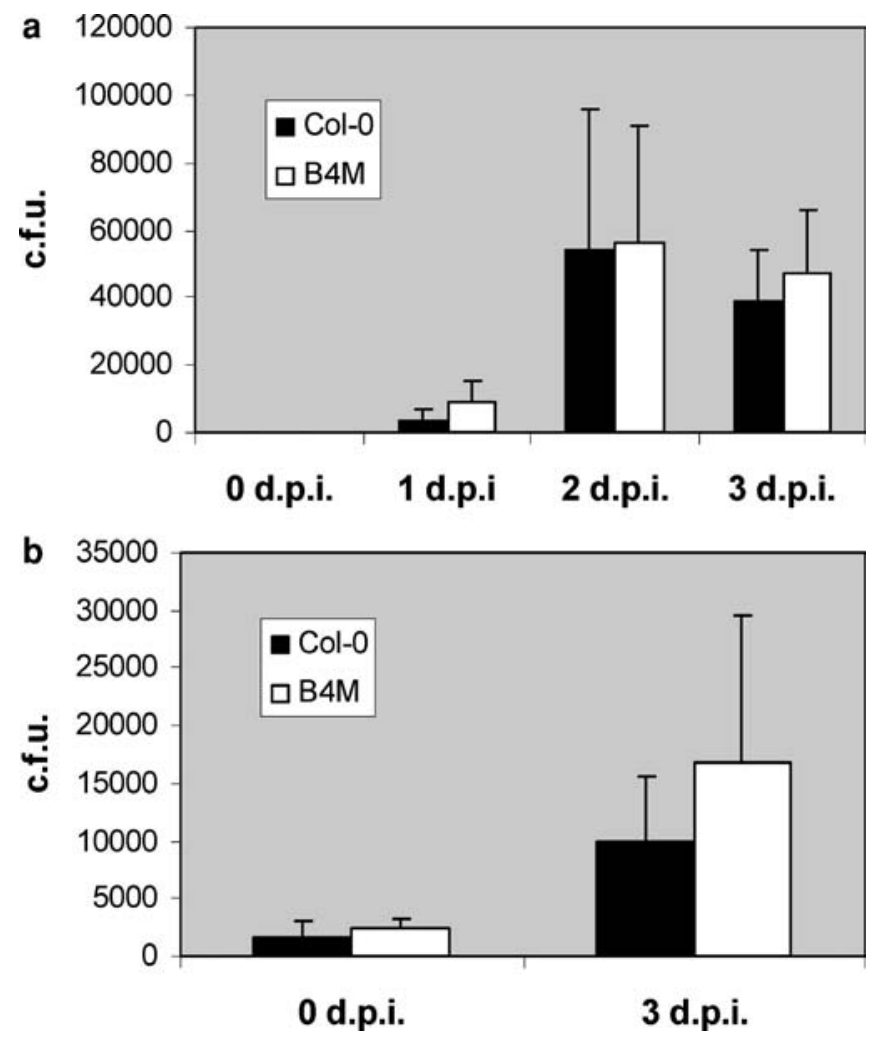

Fig. 7 a, b Growth of virulent bacterium Pseudomonas syringae DC3000 is similar in Col-0 and in B4M plants (a). Arabidopsis leaves containing the $\mathrm{B} 4 \mathrm{M}$ transgene, as indicated, were inoculated with bacterial strain $P$. syringae DC3000. Bacterial titer was determined at times $0,1,2$ and 3 days after inoculation (d.p.i.). The B4M transgene does not significantly interfere with growth of these virulent bacteria. b Growth of avirulent bacterium Pseudomonas syringae DC3000 avrRPM1 is restricted in B4M plants as in wild type. Leaves of WT or B4M plants were inoculated with bacterial strain Pseudomonas syringae DC3000 containing avirulence gene avrRPM1. Bacterial titer was determined at times 0 and 3 d.p.i. The $\mathrm{B} 4 \mathrm{M}$ transgene does not interfere with the hypersensitive response caused by avrRPM1. c.f.u., colony forming units per $\mathrm{mg}$ fresh weight. Each value is the average of at least three experiments proteasome pathway has features distinct from HR and other currently studied forms of PCD (see also Discussion section). A ubR48 transgene under control of an inducible promoter would increase versatility of the system. In particular, plants could be grown without damaging transgene expression, and effects could be studied after induction. We placed an octa-ubiquitin R48 gene under control of the dexamethasone (Dex)inducible promoter (Aoyama and Chua 1997; construct pTARV8, see Materials and methods). Figure 8 shows a schematic drawing of the transgene (panel a), and an induction experiment documented by RNA gel blot (panel b). Unlike the $35 \mathrm{~S}$ promoter-driven construct used in the previous experiments, which carried the murine DHFR cDNA as a nontranslated sequence extension, the inducible construct had the ubR48 units fused in frame to DHFR. DHFR is a small, monomeric, stable protein frequently used as a test protein. In $\mathrm{Ara}$ bidopsis, it can serve as a marker gene (Bachmair et al. 1993; Hadi et al. 2002), and can be expressed at high levels without deleterious effect (Potuschak et al. 1998; Stary et al. 2003). Consequences of expression of the Dex-inducible construct can therefore be attributed exclusively to the presence of ubR48. Plant line RV86-5, which carries a T-DNA insert on the distal end of chromosome 5 , is phenotypically identical to wild-type plants in the absence of Dex. When the medium is supplemented with $0.7 \mu \mathrm{M}$ Dex, seedlings die soon after germination (Fig. 9a vs. b). This line was used for further studies.

We used line RV86-5 to study kinetic aspects of cell death induction. Seeds were incubated in liquid culture. After 14 days of growth, ubR48 expression was initiated by addition of Dex to a final concentration of $100 \mu \mathrm{M}$. Visual differences were first observed 7 days after Dex addition. Panels $\mathrm{c}$ and $\mathrm{d}$ of Fig. 9 show the difference between noninduced and induced state 15 days after treatment. Experiments using plants grown for 2 weeks on Agar plates, followed by distribution of Dex-containing liquid, gave similar results (Fig. 9e vs. f). DNA content was analyzed during induction (Fig. 10). Fast forms of PCD, such as the hypersensitive response, result in loss of DNA, and DNA laddering may be observed. In contrast, senescence, a much slower form of PCD, is known to defer DNA loss to its latest stages (for review, see Buchanan-Wollaston et al. 2003). No significant difference was observed in DNA content of Dexinduced and control plants grown in liquid culture during the first 2 weeks of induction (Fig. 10). Furthermore, nucleosome-sized DNA fragments were not observed (data not shown).

Next, we determined whether additional stress can speed up the relatively slow kinetics of cell death induction observed after Dex exposure of the germinated seedlings. We chose increased light intensity (continuous light) as a stress factor. Continuous light instead of a $16 \mathrm{~h}$ light $/ 8 \mathrm{~h}$ dark cycle can indeed aggravate and accelerate the consequences of Dex induction, and leaf color differences were first observed 
Fig. 8 a, b Inducible expression of ubR48. a The transgene (top) consists of a dexamethasone (Dex)-inducible promoter, eight ubiquitin ubR48 variant units, a murine dihydrofolate reductase (DHFR), and transcriptional termination signals from the pea rbcS $3 \mathrm{~A}$ gene (term). The ubR48 units and DHFR are translated as one polypeptide (shown below). Ubiquitinspecific proteases of the cell cleave the polyprotein to yield ubR48 and DHFR. b Induction kinetics of the transgene mRNA in plant material submerged in Dex-containing liquid medium. Ribosomal protein RPL4 mRNA was detected as a loading control a

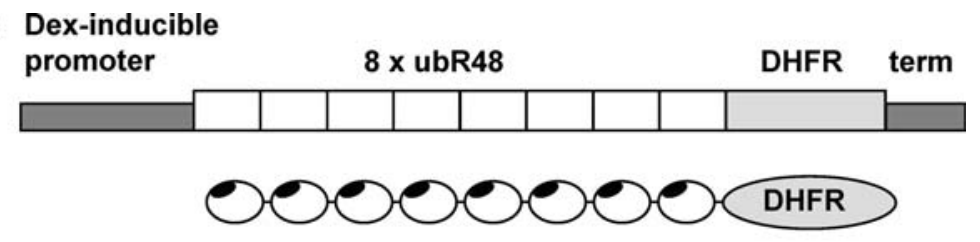

b

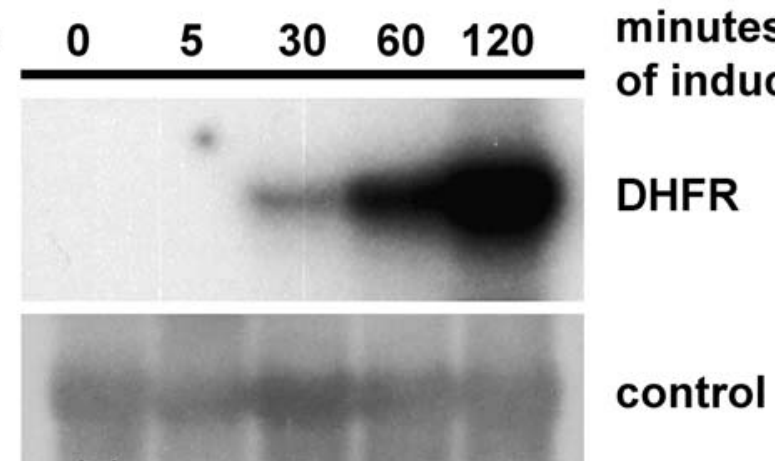

after 4 days. Whereas untreated control plants can easily cope with the increased light intensity (Fig. 9e vs. g), Dex-treated plants are noticeably more affected in continuous light after 7 days (Fig. 9f vs. h). This situation is reminiscent of certain lesion mimic mutants, whose phenotype is restricted to long day conditions (Dietrich et al. 1994; see Discussion).

Isolation of mutants resistant to ubR48-induced cell death

Line RV86-5 was also used for mutagenesis to generate mutant plants that survive the otherwise lethal concentration of Dex used in the seedling assay of Fig. 9b. Seeds of line RV86-5 were treated with ethyl methanesulfonate $(0.1 \%)$ for 12 and $16 \mathrm{~h}$. Seedlings were germinated and grown for seed harvest. $\mathbf{M}_{2}$ seeds were sown on agar medium containing $0.7 \mu \mathrm{M}$ dexamethasone. Because seedlings that do not express the transgene survive perfectly on Dex-containing medium, we expected that transgene silencing would create a large number of false positives. We therefore included an additional selection step by adding $0.5 \mathrm{mg} / 1$ methotrexate (MTX) together with Dex to the growth medium. As emphasized above, the inducible construct co-expresses murine dihydrofolate reductase (DHFR), which confers resistance to MTX (Fig. 8a; Bachmair et al. 1993). Therefore, plants that do not express the transgene cannot survive on Dex-MTX medium. Plants expressing the transgene, on the other hand, die due to the lethal effects of ubR48. Only plants that express the transgene, but carry an additional suppressor mutation, can survive on the medium. Surviving seedlings were grown to maturity on soil, and seeds from these candidates were re-tested. Positive candidates were also assayed for the expression level of the transgene. Figure 11 shows RNA gel blot experiments with mutants later named SUD1-1, and sud2-sud5 (suppressor of ubiquitin R48-induced cell death). The extent of transgene induction in mutants is comparable to the control level. Figure 11 also indicated that none of the candidates had a re-arranged transgene with reduced number of ubiquitin repeats, which would also reduce the level of ubR48 expression. The number of ubR48 repeats was independently analyzed by PCR amplification of the transgene (data not shown).

Genetic analysis by crossing to the RV86-5 progenitor line and to other candidate lines indicated that mutants with single nuclear mutations were obtained. Approximately, half of these mutations were dominant. Only one dominant line was retained for further analysis and named SUD1-1. Four recessive mutants were called sud2-sud5. Figure 12b shows mutant line SUD1-1 growing on the MTX- and Dex-containing medium, in comparison with the unmutated RV86-5 line (Fig. 12a). Interestingly, SUD1-1 was also more resistant to the proteasome inhibitor MG132 (Fig. 12d vs. c).

\section{Discussion}

Inhibition of the ubiquitin-proteasome pathway

Manipulation of essential pathways by expression of dominant negative variants of pathway components can reveal connections to downstream events, features of pathway regulation, and other characteristics. These features may otherwise go undetected due to functional redundancy, or due to the fact that essential components are not amenable to analysis based on loss-of-function alleles. We have expressed a dominant negative variant of ubiquitin to perturb ubiquitin-dependent protein turnover. A ubiquitin variant (ubR48), in which Lys 48 is replaced by Arg, does not support formation of ubiquitin-ubiquitin linkages via position 48. Because the latter linkages are essential for recognition of proteolytic substrates by the proteasome, the variant has an inhibitory effect on ubiquitin-dependent proteolysis. 

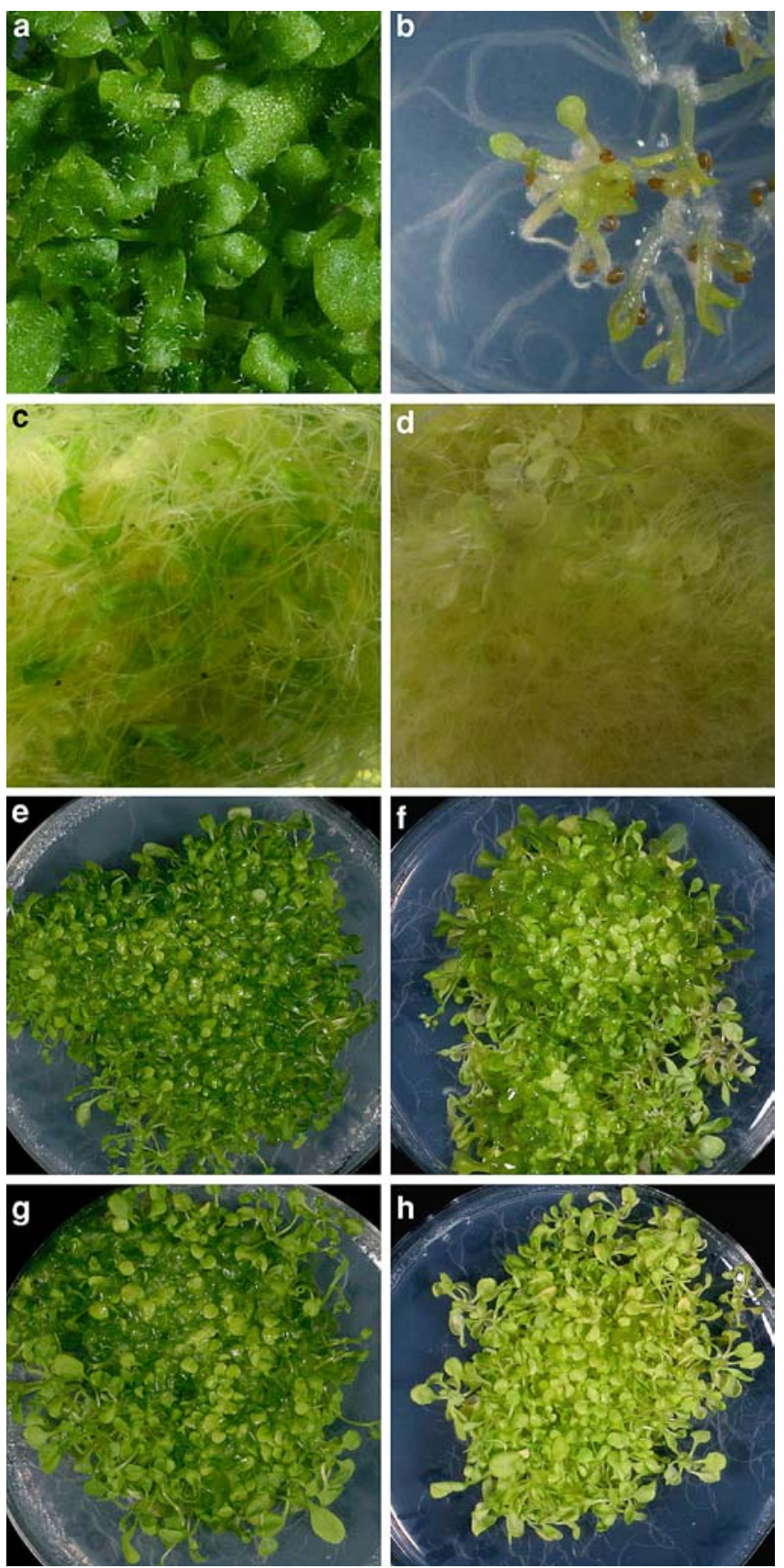

Fig. 9 a-h Consequences of ubR48 transgene induction under different conditions. a Control plants of line RV86-5, no dexamethasone (Dex) added; b Dex at a concentration of $0.7 \mu \mathrm{M}$ in the agar medium causes growth arrest and death of line RV865 at the seedling stage. $\mathbf{c}-\mathbf{h}$ ubR48 induction at later stages of development. c, d Seeds were germinated and grown for 2 weeks in liquid culture. c Control without Dex. d Dex was added to $100 \mu \mathrm{M}$. Pictures were taken 15 days after Dex addition, showing root and shoot material intermingled in the Erlenmeyer flask. f, h Seeds were germinated and grown on agar medium for 3 weeks. Thereafter, Dex was spread to a final concentration of $20 \mu \mathrm{M}$. e, g Controls without Dex. e, f Seedlings were grown on plates under a $16 \mathrm{~h}$ light/ $8 \mathrm{~h}$ dark regime and were photographed 7 days after Dex addition. $\mathbf{g}, \mathbf{h}$ Same as e, f, but plates were kept in continuous light, indicating that additional stress factors such as increased light exposure can speed up cell death induction
The genetic method of inhibiting the ubiquitin-proteasome pathway used in this study may have consequences similar to the use of proteasome inhibitors. Recent studies of the application of proteasome inhibitors to yeast and myeloma cells demonstrated that, in spite of the high number of substrate proteins for the pathway, the effects on gene expression are surprisingly specific (Fleming et al. 2002; Mitsiades et al. 2002). In mammalian cells, both major cell death pathways, the intrinsic "mitochondrial" pathway, and the extrinsic pathway normally triggered by death-inducing ligands, are induced by proteasome inhibitor treatment. In plant cells, proteasome inhibition also leads to apoptosis-like cell death (Kim et al. 2003).

In this work, Arabidopsis thaliana was used to express ubR48. We observe a number of changes in gene expression and in phenotype. The most noteworthy phenotypic change is a tendency to initiate cell death. We see two possible explanations for the cell death phenotype. Firstly, the combined effect of several, individually sublethal changes caused by ubR48 expression leads to cell death. Secondly, ubiquitylation in plants, as in animals, has a specific role in programmed cell death (PCD), and this hypothetical role in PCD is uncovered by ubR48 expression. The results presented, particularly the isolation of single locus suppressor mutations, are more consistent with the latter possibility.

In one experiment, a ubR48 expressing line was crossed to a line expressing an easily detectable metabolically unstable protein, cyclin B1;1, fused to GUS, under control of the cyclin promoter. Fusion genes of this type are useful to stain mitotic cells (Donnelly et al. 1999). As cyclins are known substrates of the ubiquitinproteasome pathway (Zachariae and Nasmyth 1999), cyclin-GUS fusions can also be used to analyze the capacity of the ubiquitin-dependent protein degradation system (see, for instance, Kwee and Sundaresan 2003). Analysis by staining for GUS enzyme activity demonstrates that ubR48 expression increases the half-life of the cyclin-GUS fusion (Fig. 4). This experiment supports the notion that ubR48 interferes with ubiquitindependent protein degradation.

Characterization of cell death events triggered by ubR48 expression

Figure 2 shows cell death symptoms on ubR48 expressing Arabidopsis plants. Many primary transformants constitutively expressing ubR48 died without setting seed. Others, however, show a pronounced phenotype only if the transgene is in the homozygous state, indicating that in these instances doubling transgene expression exceeds a threshold level necessary for causing phenotypic changes. A characteristic zone of cell death in such transgenic plants lies at the base of siliques. Cell death in this zone frequently starts on the 
Fig. 10 DNA content of ubR48-expressing seedlings. Seedlings grown in liquid culture, as shown in Fig. 9c and $\mathrm{d}$, were used for DNA extraction at the indicated time points after Dex induction. Each column represents the average of three independent experiments. The apparent decrease in DNA content after 1 week is ascribed to expansion growth during this time

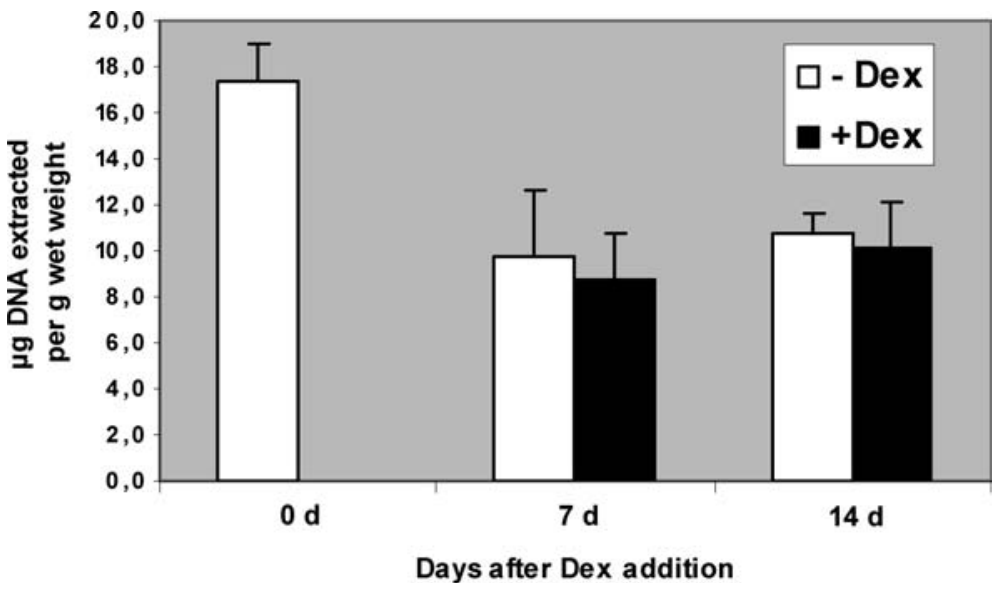

adaxial side. Continued growth on the abaxial side results in bending of the silique (Fig. 3).

The cell death events resulting from constitutive ubR48 expression in Arabidopsis were accompanied by generation of reactive oxygen intermediates (ROIs; Fig. 3). ROIs can be detected during cell death triggered by a variety of stimuli, including ozone and incompatible pathogens (for review, see Overmyer et al. 2003). They are also manifest in those zones of the silique that disintegrate in order to allow seed dispersal (Fig. $3 \mathrm{~b}$ and c, arrowheads), suggesting that occurrence of ROIs is also a feature of developmentally induced cell death. Some cell death events are accompanied not only by generation of ROIs but also by high levels of SA. Generation of both substances may be linked in a positive feedback loop. Surprisingly, the SA-inducible PR1 gene is not expressed in B4M16 plants (but can be induced by exogenous application of SA; Fig. 6),

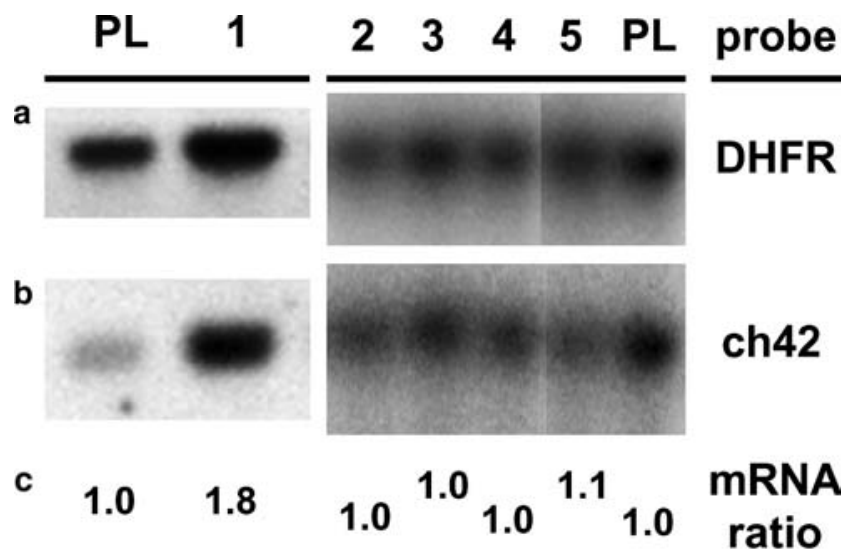

Fig. 11 a-c Analysis of transgene levels in sud (suppressor of ubiquitin R48-induced cell death) mutants. Eight hours after transgene induction by Dex addition, RNA was isolated and used for a gel blot. a DHFR probe detects ubR48 transgene RNA. b Chlorata 42 loading control. c Ratio of induced mRNA to control mRNA in comparison to the unmutated RV86-5 line (arbitrarily set to 1) indicates that the mutants selected can express the transgene similar to the nonmutagenized parental line RV86-5 (PL). Lanes 1 to 5 show mutant plant lines designated SUD1-1 and sud2-sud5, respectively suggesting that SA levels are not significantly increased in line B4M16. This finding in Arabidopsis represents a difference to the previous results obtained with ubR48 expressing tobacco plants, which accumulate free SA and SA glucoside (Conrath et al. 1998).

We also wanted to know whether SA, even at low levels, is instrumental in mediating cell death events triggered by ubR48 expression. To that end, the SAdestroying enzyme salicylate hydroxylase was co-expressed with ubR48 in Arabidopsis plants. A transgenic line expressing the $n a h G$ gene from Pseudomonas putida under control of the $35 \mathrm{~S}$ promoter was crossed to a ubR48 expressing line. We observed no reduction in the extent of cell death (cf. Fig. 5). One conclusion from this experiment is that SA is not necessary for cell death triggered by ubR48 expression. Independence of cell death events from presence of SA was also found in socalled lsd mutants (Hunt et al. 1997). This situation contrasts with cell death induction triggered by some Arabidopsis disease resistance genes, which is heavily dependent on SA generation (Xiao et al. 2003), or from ozone-induced lesion formation, which also requires SA (Rao et al. 2002), and may in fact indicate that perturbation of ubiquitin-dependent proteolysis interacts with cell death components "downstream" of the point where SA is beneficial during HR, or induces a distinct set of cell death components.

The level of expression was tested for a limited set of genes. The test genes are primarily associated with pathogen defense. PR-1, for instance, is known to be induced by pathogens, and by SA (Lebel et al. 1998). PR-1 is not systemically induced in the ubR48 Arabidopsis plants. It can be induced by exogenous application of SA, to a somewhat higher level than in nontransgenic wild-type plants (Fig. 6, probe PR-1, lanes 3 and 11). PR-2, another pathogenesis-related transcript, is constitutively expressed in B4M16 (ubR48 expressing) plants (Fig. 6, probe PR-2, lanes 9 to 12). Inclusion of nahG (Fig. 6 probe PR-2, lanes 13 to 16), or exogenous application of Me-JA, reduces the expression level, but does not interfere with a significant basal level of expression. We conclude that basal expression of PR-2, 

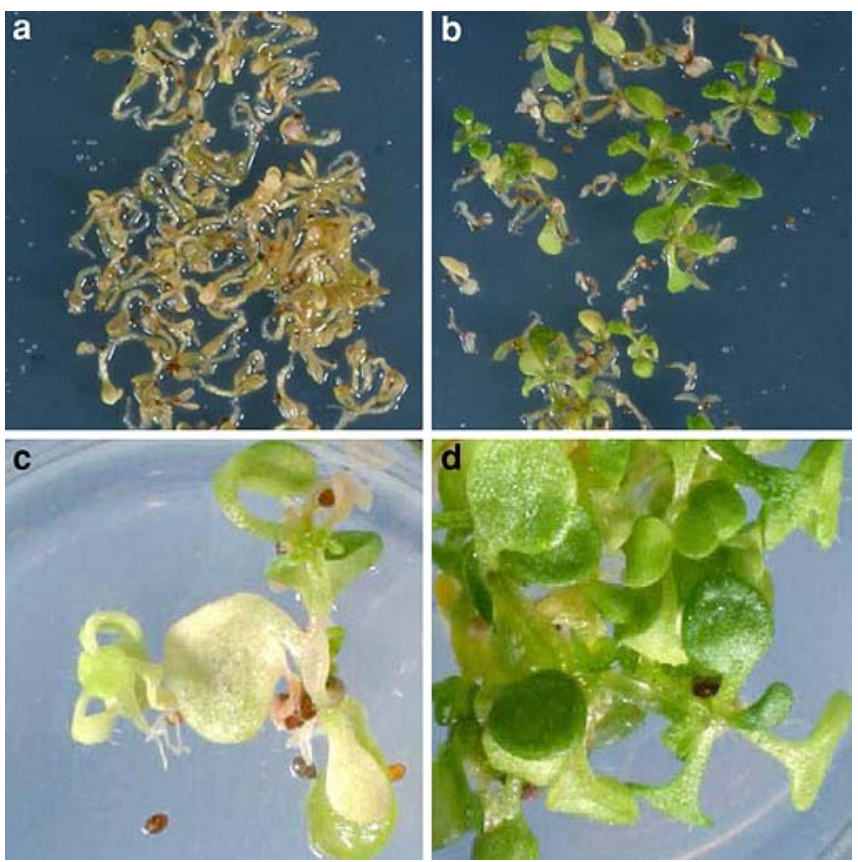

Fig. 12 a-d SUD 1-1 mutation suppresses Dex-induced cell death and causes increased resistance to a proteasome inhibitor. a, b Plant line containing SUD1-1 mutation survives Dex treatment. a Unmutated transgenic line RV86-5 on agar plates containing Dex $(0.7 \mu \mathrm{M})$ and MTX $(0.5 \mu \mathrm{g} / 1)$. b Seeds of mutant line survive the same condition. c, d SUD1-1 plants are also more resistant to proteasome inhibitor MG132. c RV86-5 seeds germinated in the presence of $200 \mu \mathrm{M}$ MG132. d Same as c with SUD1-1 seeds

triggered by ubR48, is independent of SA or JA, a property shared with cell death induction. This conclusion is consistent with the previously reported difference in induction of PR-1 versus PR-2 (Nawrath and Métraux 1999).

Two of the probes used in the RNA gel blot experiment are known to be JA-inducible. The expression of Thi2.1, a thionin gene (Fig. 6, probe Thi), depends strictly on the exogenous addition of Me-JA in our experimental setup. These findings suggest that ubR48 expressing Arabidopsis plants do not contain elevated levels of JA, and that ubR48 expression does not impinge on JA-mediated regulatory circuits as revealed by mutants with constitutive Thi2.1 expression (Nibbe et al. 2002). In contrast, the defensin gene Pdf1.2 is induced both by exogenous Me-JA application and by expression of ubR48. Interestingly, its expression is almost abolished in presence of $n a h G$, suggesting a stimulatory effect of low levels of SA (Fig. 6 probe Pdf, lane 9 vs. 13). However, even a mild abiotic stress, such as application of water onto leaves, can efficiently induce Pdf1.2 in the B4M nahG background (Fig. 6 probe Pdf, lane 14).

Using the bacterial pathogen Pseudomonas syringae DC3000, we demonstrated that multiplication of a virulent strain is not significantly different in the B4M background compared to Col-0 wild type (Fig. 7a). Likewise, the hypersensitive response against an aviru- lent pathogen is not compromised by ubR48 expression (Fig. 7b).

Inducible ubR48 expression (Fig. 8) was employed to study kinetic parameters of cell death induction. We found that for germinated seedlings (age 2-3 weeks), an induction period of approximately 7 days was necessary before visual symptoms were clearly apparent. Plants grown either in liquid culture (Fig. 9c vs. d; picture taken 15 days postinduction) or on plates (Fig. 9e vs. f; picture taken 7 days postinduction) showed leaf yellowing. Inclusion of the inducing Dex during seed germination apparently acts somewhat faster (Fig. 9b vs. a).

It is possible that ubR48 expression also induces cell death pathways typical of senescence, and that these pathways dominate in plants grown in low light tissue culture conditions. In that case, DNA degradation would occur only very late, long after the onset of visual symptoms (for review, see Buchanan-Wollaston et al. 2003). Analysis of DNA content supports this interpretation, in that no significant difference was observed between Dex-induced and control cultures (Fig. 10). The apparent decrease of DNA content within the first week after induction in both samples may be due to expansion growth.

We wanted to know whether additional stress factors, as encountered by soil-grown plants, can induce a faster cell death response, and/or a response involving additional pathways as compared to growth in sterile culture. In this context, it is interesting that the Arabidopsis lesion mimic mutants $l s d l$ and $l s d 3$ are almost symptomfree when grown in short days, whereas cell death develops under long light exposure (Dietrich et al. 1994). Induction experiments, shown in Fig. 9a to f, employed low light intensities. We therefore carried out an experiment under continuous higher light intensity (Fig. 9g and $\mathrm{h}$ ). The additional stress caused aggravation of the phenotype, both regarding severity and kinetics of symptom appearance. It is therefore possible that the lesion phenotypes of adult greenhouse-grown plants result from the transgene in combination with a variety of normally harmless additional stress factors.

\section{Mutants resistant to the effects of ubR48 expression}

The Dex-inducible transgene was also used to isolate mutants that do not react to ubR48 expression by cell death induction. Several different mutations, segregating in a mendelian fashion, were obtained. The mutants grow normal under greenhouse conditions and have no obvious phenotypic alterations, arguing for changes in distinct, rather specialized pathways. This result is consistent with a specific role for ubiquitylation in PCD. Preliminary characterization of five different complementation groups showed that one dominant mutation, SUD1-1 (suppressor of ubiquitin R48-induced cell death 1-1), whose phenotype is shown in Fig. 12b (vs. Fig.12a), also confers increased resistance to the pro- 
teasome inhibitor, MG132 (Fig. 12d vs. c). This finding implies that decreased efficiency of the ubiquitin-proteasome pathway by either ubR48 expression, or by proteasome inhibition, can be balanced by the same mutation. It should be emphasized, however, that other mutants obtained from the screen are not more resistant to MG132, indicating that suppression of ubR48-induced phenotypes can occur at more than one level.

Taken together, the experiments indicate that inhibition of ubiquitin-dependent protein degradation can induce (a) cell death program(s) in plants, as it does in animals. Additional changes, such as alterations in plant defense gene expression, may be secondary effects. The molecular nature of the primary event, and of the subsequent steps of cell death execution, are unclear at the moment. However, isolation of suppressor mutants (Figs. 11, 12) shall give access to molecular details of plant cell death and its connections to the ubiquitinproteasome pathway.

Acknowledgements We wish to thank J. Celenza (Boston University, Boston, USA), J. Dangl, and M. A. Torres (University of North Carolina, Chapel Hill, USA) and Syngenta Biotechnology Inc. (Research Triangle Park, USA) for plants and bacteria, S. Stary (Univ. of Vienna, Vienna, Austria) for sharing materials, F. Hadacek for help with unpublished experiments, and M.-L. Kalda for photography. This work was supported by the Austrian Science Foundation FWF (grant P 13927), and by the Max Planck Society.

\section{References}

Aoyama T, Chua N-H (1997) A glucocorticoid-mediated transcriptional induction system in transgenic plants. Plant $\mathrm{J}$ 11:605-612

Aravind L, Dixit VM, Koonin EV (2001) Apoptotic molecular machinery: vastly increased complexity in vertebrates revealed by genome comparisons. Science 291:1279-1284

Ausubel FM, Brent R, Kingston RF, Moore DO, Seidman JG, Smith JA, Struhl K (1987) Current protocols in molecular biology. Wiley, New York

Bachmair A, Becker F, Masterson RV, Schell J (1990) Perturbation of the ubiquitin system causes leaf curling, vascular tissue alterations and necrotic lesions in a higher plant. EMBO J 9:4543-4549

Bachmair A, Becker F, Schell J (1993) Use of a reporter transgene to generate Arabidopsis mutants in ubiquitin-dependent protein degradation. Proc Natl Acad Sci USA 90:418-421

Bachmair A, Novatchkova M, Potuschak T, Eisenhaber F (2001) Ubiquitylation in plants: a post-genomic look at a post-translational modification. Trends Plant Sci 6:463-470

Baek D, Nam J, Koo YD, Kim DH, Lee J, Jeong JC, Kwak S-S, Chung WS, Lim CO, Bahk JD, Hong JC, Lee SY, KawaiYamada M, Uchimiya H, Yun D-J (2004) Bax-induced cell death of Arabidopsis is mediated through reactive oxygendependent and -independent processes. Plant Mol Biol 56:15-27

Bartke T, Pohl C, Pyrowolakis G, Jentsch S (2004) Dual role of BRUCE as an antiapoptotic IAP and a chimeric E2/E3 ubiquitin ligase. Mol Cell 14:801-811

Becker F, Buschfeld E, Schell J, Bachmair A (1993) Altered response to viral infection by tobacco plants perturbed in ubiquitin system. Plant J 3:875-881

Bohlmann H, Vignutelli A, Hilpert B, Miersch O, Wasternack C, Apel K (1998) Wounding and chemicals induce expression of the Arabidopsis thaliana gene Thi2.1, encoding a fungal defense thionin, via the octadecanoid pathway. FEBS Lett 437:281-286
Buchanan-Wollaston V, Earl S, Harrison E, Mathas E, Navabpour S, Page T, Pink D (2003) The molecular analysis of leaf senescence-a genomics approach. Plant Biotech J 1:3-22

Christensen CA, Gorsich SW, Brown RH, Jones LG, Brown J, Shaw JM, Drews GN (2002) Mitochondrial GFA2 is required for synergid cell death in Arabidopsis. Plant Cell 14:2215-2232

Conrath U, Klessig DF, Bachmair A (1998) Tobacco plants perturbed in the ubiquitin-dependent protein degradation system accumulate callose, salicylic acid, and pathogenesis-related protein 1. Plant Cell Rep 17:876-888

Curtis MJ, Wolpert TJ (2002) The oat mitochondrial permeability transition and its implication in victorin binding and induced cell death. Plant J 29:295-312

Dietrich RA, Delaney TP, Uknes SJ, Ward ER, Ryals JA, Dangl J (1994) Arabidopsis mutants simulating disease resistance response. Cell 77:565-577

Donnelly PM, Bonetta D, Tsukaya H, Dengler RE, Dengler NG (1999) Cell cycling and cell enlargement in developing leaves of Arabidopsis. Dev Biol 215:407-419

Epple P, Apel K, Bohlmann H (1995) An Arabidopsis thaliana thionin gene is inducible via a signal transduction pathway different from that for pathogenesis-related proteins. Plant Physiol 109:813-820

Fleming JA, Lightcap ES, Sadis S, Thoroddsen V, Bulawa CE, Blackman RK (2002) Complementary whole-genome technologies reveal the cellular response to proteasome inhibition by PS-341. Proc Natl Acad Sci USA 99:1461-1466

Glotzer M, Murray AW, Kirschner M (1991) Cyclin is degraded by the ubiquitin pathway. Nature 349:132-138

Grant MR, Godiard L, Straube E, Ashfield T, Lewald J, Sattler A, Innes RW, Dangl JL (1995) Structure of the Arabidopsis RPMI gene enabling dual specificity disease resistance. Science 269:843-846

Gray J (2004) Programmed cell death in plants. Blackwell, Oxford

Hadi MZ, Kemper E, Wendeler E, Reiss B (2002) Simple and versatile selection of Arabidopsis transformants. Plant Cell Rep 21:130-135

Hare PD, Seo HS, Yang J-Y, Chua N-H (2003) Modulation of sensitivity in plant signaling by proteasomal destabilization. Curr Opin Plant Biol 6:453-462

van der Hoorn RAL, Jones JD (2004) The plant proteolytic machinery and its role in defence. Curr Opin Plant Biol 7:400-407

Hunt MD, Delaney TP, Dietrich RA, Weymann KB, Dangl JL, Ryals JA (1997) Salicylate-independent lesion formation in Arabidopsis lsd mutants. Molec Plant Microbe Interact 5:531536

Jamir Y, Guo M, Oh HS, Petnicki-Ocwieja T, Chen SR, Tang XY, Dickman MB, Collmer A, Alfano JR (2004) Identification of Pseudomonas syringae type III effectors that can suppress programmed cell death in plants and yeast. Plant $\mathbf{J}$ 37:554-565

Kawai-Yamada M, Jin L, Yoshinaga K, Hirata A, Uchimiya H (2001) Mammalian Bax-induced plant cell death can be downregulated by overexpression of Arabidopsis Bax Inhibitor-1 (AtBI-1). Proc Natl Acad Sci USA 98:12295-12300

Kim M, Ahn J-W, Jin U-H, Choi D, Paek K-H, Pai H-S (2003) Activation of programmed cell death pathway by inhibition of proteasome function in plants. J Biol Chem 278:1940619415

Kisselev AF, Goldberg AL (2001) Proteasome inhibitors: from research tools to drug candidates. Chemy Biol 8:739-758

Koncz C, Mayerhofer R, Koncz-Kalman Z, Nawrath C, Reiss B, Rédei GP, Schell J (1990) Isolation of a gene encoding a novel chloroplast protein by T-DNA tagging in Arabidopsis thaliana. EMBO J 9:1337-1346

Kwee H-S, Sundaresan V (2003) The NOMEGA gene required for female gametophyte development encodes the putative APC6/ CDC16 component of the anaphase promoting complex in Arabidopsis. Plant J 36:853-866

Lacomme C, Santa Cruz S (1999) Bax-induced cell death in tobacco is similar to the hypersensitive response. Proc Natl Acad Sci USA 96:7956-7961 
Lam YA, Lawson TG, Velayutham M, Zweier JL, Pickart CM (2002) A proteasomal ATPase subunit recognizes the polyubiquitin degradation signal. Nature 416:763-767

Lebel E, Heifetz P, Thorne L, Uknes S, Ryals J, Ward E (1998) Functional analysis of regulatory sequences controlling PR-1 gene expression in Arabidopsis. Plant J 16:223-233

Ling R, Colón E, Dahmus ME, Callis J (2000) Histidine-tagged ubiquitin substitutes for wild-type ubiquitin in Saccharomyces cerevisiae and facilitates isolation and identification of in vivo substrates of the pathway. Anal Biochem 282:54-64

MacFarlane M, Merrison W, Bratton SB, Cohen GM (2002) Proteasome-mediated degradation of Smac during apoptosis: XIAP promotes Smac ubiquitination in vitro. J Biol Chem 277:36611-36616

Manners JM, Penninckx IAMA, Vermaere K, Kazan K, Brown RL, Morgan A, Maclean DJ, Curtis MD, Cammue BPA, Broeckaert WF (1998) The promoter of the plant defensin gene PDF1.2 from Arabidopsis is systemically activated by fungal pathogens and responds to methyl jasmonate but not to salicylic acid. Plant Mol Biol 38:1071-1080

Matsumura H, Nirasawa S, Kiba A, Urasaki N, Saitoh H, Ito M, Kawai-Yamada M, Uchimiya H, Terauchi R (2003) Overexpression of Bax inhibitor suppresses the fungal elicitor-induced cell death in rice (Oryza sativa L.) cells. Plant J 33:425-434

Mitsiades N, Mitsiades CS, Puolaki V, Chauhan D, Fanourakis G, Gu X, Bailey C, Joseph M, Libermann TA, Treon SP, Munshi NC, Richardson PG, Hideshima T, Anderson KC (2002) Molecular sequelae of proteasome inhibition in human multiple myeloma cells. Proc Natl Acad Sci USA 99:14374-14379

Moon J, Parry G, Estelle M (2004) The ubiquitin-proteasome pathway and plant development. Plant Cell 16:3181-3195

Nawrath C, Métraux J-P (1999) Salicylic acid induction-deficient mutants of Arabidopsis express $P R-2$ and $P R-5$ and accumulate high levels of camalexin after pathogen inoculation. Plant Cell 11:1393-1404

Nibbe M, Hilpert B, Wasternack C, Miersch O, Apel K (2002) Cell death and salicylate- and jasmonate-dependent stress responses in Arabidopsis are controlled by single cet genes. Planta 216:120-128

Overmyer K, Brosché M, Kangasjärvi J (2003) Reactive oxygen species and hormonal control of cell death. Trends Plant Sci $8: 335-342$

Overmyer K, Tuominen H, Kettunen R, Betz C, Langebartels C, Sandermann Jr H, Kangasjärvi J (2000) Ozone-sensitive Arabidopsis rcdl mutant reveals opposite roles for ethylene and jasmonate signaling pathways in regulating superoxide-dependent cell death. Plant Cell 12:1849-186

Peng J, Schwartz D, Elias JE, Thoreen CC, Cheng D, Marsischky G, Roelofs J, Finley D, Gygi SP (2003) A proteomics approach to understanding protein ubiquitination. Nature Biotechol 21:921-926

Penninckx IAMA, Eggermont K, Terras FRG, Thomma BPHJ, De Samblanx GW, Buchala A, Métraux J-P, Manners JM, Broeckaert WF (1996) Pathogen-induced systemic activation of a plant defensin gene in Arabidopsis follows a salicylic acidindependent pathway. Plant Cell 8:2309-2323

Pickart CM (2001) Mechanisms underlying ubiquitination. Annu Rev Biochem 70:503-533

Potuschak T, Stary S, Schlögelhofer P, Becker F, Nejinskaia V, Bachmair A (1998) PRT1 of Arabidopsis thaliana encodes a component of the plant N-end rule pathway. Proc Natl Acad Sci USA 95:7904-7908

Rao MV, Lee H, Davis KR (2002) Ozone-induced ethylene production is dependent on salicylic acid, and both salicylic acid and ethylene act in concert to regulate ozone-induced cell death. Plant J 32:447-456

Ritter C, Dangl JL (1995) The avrRPMI gene of Pseudomonas syringae pv. maculicola is required for virulence on Arabidopsis. Molec Plant-Microbe Interact 8:444-453
Schenk PM, Kazan K, Wilson I, Anderson JP, Richmond T, Somerville SC, Manners JM (2000) Coordinated plant defense responses in Arabidopsis revealed by microarray analysis. Proc Natl Acad Sci USA 97:11655-11660

Schlögelhofer P, Bachmair A (2002) A test of fusion protein stability in the plant Arabidopsis thaliana reveals degradation signals from ACC synthase and from the plant $\mathrm{N}$-end rule pathway. Plant Cell Rep 21:174-179

Schlögelhofer P, Nizhynska V, Feik N, Chambon C, Potuschak T, Wanzenböck E-M, Schweizer D, Bachmair A (2002) The upstream Sal repeat-containing segment of Arabidopsis thaliana ribosomal DNA intergenic region (IGR) enhances the activity of adjacent protein-coding genes. Plant Mol Biol 49:655-667

Schwechheimer C, Schwager K (2004) Regulated proteolysis and plant development. Plant Cell Rep 23:353-364

Smalle J, Vierstra RD (2004) The ubiquitin 26S proteasome proteolytic pathway. Annu Rev Plant Biol 55:555-590

Spoel SH, Koornneef A, Claessens SMC, Korzelius JP, Van Pelt JA, Mueller MJ, Buchala AJ, Métraux J-P, Brown R, Kazan K, Van Loon LC, Dong X, Pieterse CMJ (2003) NPR1 modulates cross-talk between salicylate- and jasmonate-dependent defense pathways through a novel function in the cytosol. Plant Cell 15:760-777

Stary S, Yin X-j, Potuschak T, Schlögelhofer P, Nizhynska V, Bachmair A (2003) PRT1 of Arabidopsis is a ubiquitin protein ligase of the plant $\mathrm{N}$-end rule pathway with specificity for aromatic amino-terminal residues. Plant Physiol 133:13601366

Sun X-M, Butterworth M, MacFarlane M, Dubiel W, Ciechanover A, Cohen GM (2004) Caspase activation inhibits proteasome function during apoptosis. Mol Cell 14:81-93

Uknes S, Mauch-Mani B, Moyer M, Potter S, Williams S, Dincher S, Chandler D, Slusarenko A, Ward E, Ryals J (1992) Acquired resistance in Arabidopsis. Plant Cell 4:645-656

Valvekens D, van Montagu M, van Lijsebettens M (1988) Agrobacterium tumefaciens-mediated transformation of Arabidopsis thaliana root explants by using Kanamycin selection. Proc Natl Acad Sci USA 85:5536-5540

Vaux DL, Silke J (2005) IAPs, RINGs and ubiquitylation. Nat Rev Mol Cell Biol 6:287-297

Wohlgemuth H, Mittelstrass K, Kschieschan S, Bender J, Weigel H-J, Overmyer K, Kangasjärvi J, Sandermann H, Langebartels $\mathrm{C}$ (2002) Activation of an oxidative burst is a general feature of sensitive plants exposed to the air pollutant ozone. Plant Cell Envir 25:717-726

Woo HR, Chung KM, Park J-H, Oh SA, Ahn T, Hong SH, Jang SK, Nam HG (2001) ORE9, an F-box protein that regulates leaf senescence in Arabidopsis. Plant Cell 13:1779-1790

Xiao S, Brown S, Patrick E, Brearley C, Turner JG (2003) Enhanced transcription of the Arabidopsis disease resistance genes RPW8.1 and RPW8.2 via salicylic acid-dependent amplification circuit is required for hypersensitive cell death. Plant Cell 15:33-45

Yang Y, Yu X (2003) Regulation of apoptosis: the ubiquitous way. FASEB J 17:790-799

Yoshida S, Ito M, Callis J, Nishida I, Watanabe A (2002) A delayed leaf senescence mutant is defective in arginyl-tRNA:protein arginyltransferase, a component of the N-end rule pathway in Arabidopsis. Plant J 32:129-137

Zachariae W, Nasmyth K (1999) Whose end is destruction: cell division and the anaphase complex. Genes Dev 13:20392058

Zeng L-R, Qu S, Bordeos A, Yang C, Baraoidan M, Yan H, Xie Q, Nahm BH, Leung H, Wang G-L (2004) Spotted leaf11, a negative regulator of plant cell death and defense, encodes a Ubox/armadillo repeat protein endowed with E3 ubiquitin ligase activity. Plant Cell 16:2795-2808 